\title{
Identifikasi Alih Fungsi Lahan Pertanian dan Kondisi Sosial Ekonomi Masyarakat Daerah Pinggiran di Kecamatan Gunungpati Kota Semarang
}

\author{
Nurma Kumala Dewi ${ }^{1}$ \\ Magister Pembangunan Wilayah dan Kota \\ Universitas Diponegoro, Semarang, Indonesia

\section{Iwan Rudiarto} \\ Magister Pembangunan Wilayah dan Kota \\ Universitas Diponegoro, Semarang, Indonesia
}

\begin{abstract}
Abstrak: Pertambahan penduduk dan perkembangan Kota Semarang yang mengarah hingga ke daerah pinggiran (wilayah peri-urban) menyebabkan kebutuhan lahan di area pinggiran kota semakin meningkat. Adanya alih fungsi lahan terutama lahan pertanian tentunya menyebabkan terjadinya perubahan kondisi sosial ekonomi masyarakat disana. Dari alih fungsi lahan tersebut sangat dimungkinkan terjadi perubahan matapencaharian penduduk. Dari yang semula menjadi petani, menjadi bukan petani, atau bahkan menjadi pengangguran. Jika dibiarkan terus-menerus, hal tersebut dapat mengancam keberlanjutan sistem livelihood masyarakat peri-urban khususnya petani. Oleh karena itu, tujuan penelitian ini adalah untuk mengidentifikasi perkembangan alih fungsi lahan pertanian menjadi lahan terbangun (nonpertanian) dan menganalisis kondisi sosial ekonomi masyarakat terkait alih fungsi lahan pertanian di sana. Pendekatan penelitian yang digunakan adalah pendekatan kuantitatif. Penelitian ini menggunakan analisis spasial untuk menghitung luas perubahan lahan dan menggambarkan kondisi sosial ekonomi masyarakat di tiap lokasi, serta analisis deskriptif kuantitatif dan analisis deskriptif komparatif untuk menggambarkan kondisi sosial ekonomi masyarakat terkait alih fungsi lahan. Teknik sampling yang dipakai menggunakan Metode Stratified Random Sampling yang membagi populasi menjadi kelompok berdasarkan jenis pekerjaan yaitu petani dan bukan petani dengan jumlah sampel 69 responden. Berdasarkan hasil penelitian, alih fungsi lahan pertanian terjadi secara progresif pada aera-area pengembangan seperti pada area dekat pusat kota, pada kawasan pendidikan, dan pada koridor yang merupakan pintu masuk ke Kecamatan Gunungpati. Bagi petani yang kehilangan lahan sawahnya mayoritas mengalami penurunan pendapatan. Hal ini dikarenakan tingkat pendidikan dan ketrampilan para petani yang terbatas atau tergolong rendah sehingga mereka tidak dapat mengakses pekerjaan formal. Selain itu, karena hilangnya lahan pertanian, saat ini mereka mencari kegiatan ekonominya masing-masing secara berbeda. Adanya perbedaan aktivitas ekonomi dan didorong masuknnya penduduk pendatang pada area mereka membuat kekerabatan antar warga menjadi memudar.
\end{abstract}

Kata kunci: alih fungsi, lahan pertanian, peri-urban, sosial ekonomi

\footnotetext{
${ }^{1}$ Korespondensi Penulis: Magister Pembangunan Wilayah dan Kota, Universitas Diponegoro, Semarang Email: nurmakumala@yahoo.com
} 


\begin{abstract}
The increasing and the development society of Semarang city which aim to the suburd of Semarang (peri urban area) give occasion to land needs in the edge area has increased. Sub district Gunungpati is one of suburd which consists of the area of peri urban of Semarang city goes to the area of development of Semarang city. The land conversion specifically of agriculture causes the change of social economic condition of society. It is possible to change the means of livelihood of the society from farmer going to non farmer, or even going to jobless. If it runs continuously, it may threaten the persistence of peri urban society livelihood specifically the farmer itself. Therefore, the purpose of the study is to identify the development of agriculture land conversion being the non agriculture (built up area) and to analysis socio economics condition of society relate to agriculture land conversion. Based on the result of the study, the agriculture land conversion is happened progressively on areas development such as the area of city center nearby, education area and corridor which goes to the entrance to sub district Gunungpati. The wide land conversion of agricultural area has became constructed area in the subdistrict over 16 years (1994-2010) for rice fields around $384.40 \mathrm{ha}$, and for dry fields around 414.41 ha. The agriculture land conversion has changed the social economic condition of society. The farmers who lose their rice filed have decreased income. It is caused by the level of education and skills of them are still low, so that way, they cannot access formal job. Besides that, because the lose of agriculture area, now they are looking for their economy differently. The existence of different economic activity, and the entry of new comer in their area create the relationship between them are faded.
\end{abstract}

Keywords: agriculture land, land conversion, peri urban, socio economic

\title{
Pendahuluan
}

Desakan kebutuhan lahan untuk pembangunan begitu kuat, sementara luas lahan tidak bertambah atau terbatas. Selama ini lahan pertanian mempunyai nilai lahanyang rendah dibanding peruntukan lahan lain (non pertanian), akibatnya lahan pertanian secara terus menerus akan mengalami konversi lahan ke nonpertanian. Padahal lahan pertanian (sawah) selain mempunyai nilai ekonomi sebagai penyangga kebutuhan pangan, juga berfungsi ekologi seperti mengatur tata air, penyerapan karbon di udara dan sebagainya (Hariyanto, 2010).

Manfaat dari adanya lahan pertanian tersebut seharusnya dapat dipertahankan, tidak untuk diabaikan karena selain mengganggu ekosistem, konversi lahan pertanian juga mengganggu kehidupan sosial ekonomi petani karena perubahan sosial ekonomi yang dirasakan biasanya cenderung ke arah yang merugikan masyarakat petani.

Konversi lahan pertanian seperti yang telah dijabarkan di atas merupakan fenomena yang tidak dapat dihindari bagi kota-kota besar seperti halnya Kota Semarang. Kota Semarang merupakan kota besar sekaligus menjadi ibukota Provinsi Jawa Tengah. Oleh karena itu, Kota Semarang menjadi tujuan urbanisasi kota-kota di sekitarnya. Hal ini mendesak terjadinya proses alih fungsi lahan pada area pinggiran Kota Semarang dari pertanian ke non pertanian.

Salah satu konversi lahan pertanian di Kota Semarang yang terjadi secara progresif yaitu di Kecamatan Gunungpati sebagai daerah pinggiran Kota Semarang. Konversi lahan tersebut juga didukung oleh adanya jasa pendidikan berupa kampus Universitas Negeri Semarang (UNNES) sehingga memacu terjadinya alih fungsi lahan di sekitarnya terutama lahan pertanian.

Konversi lahan pertanian di Kecamatan Gunungpati seharusnya tidak boleh dibiarkan secara bebas mengingat aturan (Perda Kota Semarang No 13 tahun 2004 tentang RDTRK BWK VIII) tentang penggunaan lahan di sana sebagian besar diperuntukkan sebagai lahan 
pertanian dan konservasi. Hal ini menjadi suatu permasalahan yang perlu diteliti untuk kemudian dapat menjadi acuan kebijakan pengendalian alih fungsi lahan di kecamatan tersebut.

\section{Rumusan Masalah}

Tingkat alih fungsi lahan pertanian ke aktivitas non pertanian di Kecamatan Gunungpati selama 10 tahun (1996-2006) sebesar 568,874 ha, atau rata-rata 56,9 ha per tahun. Adapun polanya dari arah timur ke barat dengan cara penetrasi. Konversi lahan pertanian tersebut telah menimbulkan dampak pengangguran $13,65 \%$, dan penurunan pendapatan sebesar $54,5 \%$. Di sisi lain, ada dampak positifnya yaitu kecamatan Gunungpati makin maju dengan kegiatan non pertanian (Arisngantiasih, 2010 dalam Hariyanto, 2010). Hariyanto juga menyebutkan bahwa pengurangan lahan sawah (tahun 2000-2009) terbesar di Kota Semarang adalah Kecamatan Gunungpati yaitu sebesar 18,43 ha.

Berdasarkan permasalahan di atas, pertanyaan penelitian ini yaitu "Bagaimana alih fungsi lahan pertanian menjadi non-pertanian di Kecamatan Gunungpati dan kondisi sosial ekonomi masyarakat terkait alih fungsi lahan di sana?”

\section{Tujuan}

Tujuan dari penelitian ini adalah untuk mengidentifikasi alih fungsi lahan pertanian menjadi lahan non-pertanian (lahan terbangun) dan kondisi sosial ekonomi penduduk terkait alih fungsi lahan tersebut.

\section{Manfaat Penelitian}

Kecamatan Gunungpati merupakan area sabuk hijau Kota Semarang dan juga masih didominasi lahan pertanian. Hal ini terkait dengan ketahanan pangan, keberlanjutan penghidupan penduduk di sana, dan juga ketersediaan ruang terbuka hijau. Oleh karena itu penelitian ini dapat menjadi masukan perencanaan yang lebih kepada tindakan preventif untuk mencegah pesatnya penggunaan lahan di luar rencana yang dapat merugikan bagi Kota Semarang.

\section{Ruang Lingkup Wilayah Penelitian}

Wilayah keseluruhan Kecamatan Gunungpati adalah 5.399 ha dengan 16 Kelurahan. Berikut beberapa justifikasi pemilihan wilayah studi penelitian yaitu antara lain:

- Merupakan salah satu daerah pinggiran Kota Semarang yang hingga saat ini karakteristik wilayahnya menyerupai daerah pedesaan dimana lahan pertanian masih mendominasi.

- Menurut hasil penelitian yang pernah dilakukan oleh Hariyanto (2010), Kecamatan Gunungpati merupakan kecamatan dengan konversi lahan sawah yang paling besar daripada kecamatan-kecamatan lain di daerah pinggiran Kota Semarang.

- Adanya Universitas Negeri yang berada di Kecamatan Gunungpati menjadi faktor pendorong terjadinya alih fungsi lahan untuk aktivitas non pertanian.

Dalam RDTRK Kota Semarang, Kecamatan Gunungpati ditetapkan dengan fungsi utama berupa lahan hijau yaitu daerah konservasi dan pertanian, sehingga alih fungsi lahan pertanian harus dibatasi. 


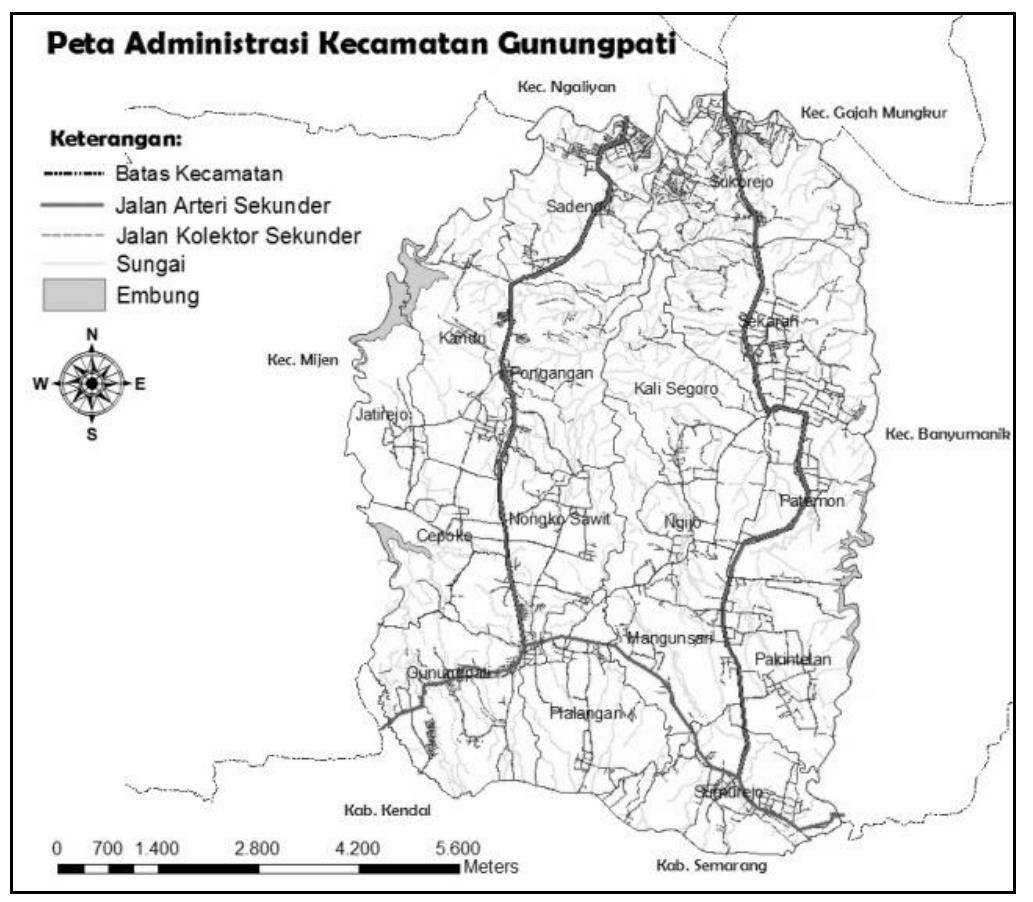

Gambar 1. Peta Administrasi Wilayah Studi

\section{Metode Penelitian}

Pendekatan penelitian yang digunakan adalah pendekatan kuantitatif dengan menggunakan teori-teori yang sudah ada sebagai variabel penelitian. Penelitian ini menggunakan data sekunder berupa citra dan peta tutupan lahan. Analisis yang dilakukan dengan menggunakan bantuan GIS untuk mengklasifikasi, memetakan, dan menghitung luas perubahan lahan, serta analisis deskriptif kuantitatif untuk mendeskripsikan perubahan lahan menggunakan tabel dan deskripsi.

Selain itu juga menggunakan survey primer untuk mengetahui kondisi sosial ekonomi masyarakat dengan observasi, kuesioner, dan wawancara. Berikut merupakan data spasial yang digunakan untuk menganalisis perubahan lahan menggunakan peta tutupan lahan.

Tabel 1. Data Spasial yang Digunakan

\begin{tabular}{c|l|l|l|l}
\hline & \multicolumn{1}{|c|}{ Jenis Data } & \multicolumn{1}{|c}{ Sumber } & Format Data & \multicolumn{1}{|c}{ Tindakan } \\
\hline 1 & $\begin{array}{l}\text { Peta Tutupan Lahan } \\
\text { tahun 1994, 2001, } \\
2006\end{array}$ & $\begin{array}{l}\text { Badan Pertanahan } \\
\text { Nasional }\end{array}$ & Shapefile & $\begin{array}{l}\text { Koreksi Peta (shapefile) } \\
\text { dengan Citra Landsat dan Alos } \\
\text { dengan tahun yang sama atau } \\
\text { mendekati }\end{array}$ \\
\hline 2 & $\begin{array}{l}\text { Peta Tutupan Lahan } \\
2010\end{array}$ & Kampus Undip & $\begin{array}{l}\text { Citra Landsat } \\
2010\end{array}$ & $\begin{array}{l}\text { Konversi menjadi shapefile, } \\
\text { klasifikasi }\end{array}$ \\
\hline
\end{tabular}


Kajian Mengenai Alih Fungsi Lahan Pertanian dan Kondisi Sosial Ekonomi Masyarakat Peri-Urban

\section{Alih Fungsi Lahan di Daerah Pinggiran}

Seiring dengan peningkatan jumlah penduduk dan perkembangan ekonomi, kebutuhan lahan untuk kegiatan nonpertanian cenderung terus meningkat. Kecenderungan tersebut menyebabkan alih fungsi lahan pertanian sulit dihindari (Iqbal dan Sumaryanto, 2007).

Menurut Mc Gee (1985) dalam Wahyuni (2002) wilayah pinggiran (periphery area) mempunyai chiri khas:

1. Sebagian besar penduduk bergantung pada sektor pertanian padi dengan kepemilikan lahan sempit.

2. Mengalami transformasi kegiatan dari pertanian ke berbagai kegiatan non pertanian, termasuk perdagangan dan industri.

Konversi lahan pertanian akan berdampak luas. Dari aspek ekonomi akan mengurangi ketahanan pangan bagi produksi pertanian. Bagi masyarakat petani akan kehilangan pekerjaan sehingga daya beli menurun karena belum tentu petani dapat pekerjaan baru yang lebih baik (Hariyanto, 2010).

\section{Konversi Lahan Pertanian}

Lahan pertanian merupakan faktor penunjang kebutuhan hidup masyarakat terutama masyarakat pedesaan dan pinggiran kota. Sebagian besar masyarakat yang ada di daerah pedesaan dan pinggiran memperoleh penghasilan atau mengandalkan usaha yang bergerak di bidang pertanian. Namun lahan pertanian atau persawahan telah dialihfungsikan menjadi lahan industri, perumahan dan permukimanyang menyebabkan produksi beras nasional akan terus menurun.

Menurut Iqbal dan Sumaryanto (2007), secara empiris lahan pertanian yang paling rentan terhadap alih fungsi adalah sawah. Hal tersebut disebabkan oleh: Kepadatan penduduk di pedesaan yang mempunyai agroekosistem dominan sawah pada umumnya jauh lebih tinggi dibandingkan agroekosistem lahan kering, Daerah pesawahan banyak yang lokasinya berdekatan dengan daerah perkotaan, infrastruktur wilayah pesawahan pada umumnya lebih baik dari pada wilayah lahan kering, serta pembangunan prasarana dan sarana pemukiman, kawasan industri, dan sebagainya cenderung berlangsung cepat di wilayah bertopografi datar, dimana pada wilayah dengan topografi seperti itu (terutama di Pulau Jawa) ekosistem pertaniannya dominan areal persawahan.

Konversi lahan pertanian di kota semarang akan berdampak luas, yakni terjadinya pergeseran struktur ketenagakerjaan, pemilikan dan penguasaan lahan, serta transformasi struktur ekonomi dari pertanian ke industri, juga mobilitas penduduk. Dari aspek ekonomi akan mengurangi ketahanan pangan bagi produksi pertanian. Bagi masyarakat petani akan kehilangan pekerjaan sehingga daya beli menurun karena belum tentu petani dapat pekerjaan baru yang lebih baik.Konversi lahan pertanian adalah suatu hal tidak dapat dihindari sebagai konsekuensi logis pembangunan, sehingga perlu sebuah perencanaan penggunaan lahan yang baik dalam rangka pengendalian konversi lahan pertanian di Kota Semarang.Untuk itu perlu diketahui lebih dahulu mengenai pola dan intensitas konversi lahan pertanian di Kota Semarang (Hariyanto, 2010).

\section{Sosial Ekonomi Masyarakat Peri-Urban}

Pada wilayah peri-urban, dimana merupakan wilayah yang berada di antara perkotaan dan pedesaan, wilayah ini mengalami perubahan bentuk pemanfaatan lahan yang dampaknya bisa berupa hilangnya lahan pertanian, adanya gejala komersialisasi dan intensifikasi lahan pertanian, sampai menurunnya produksi dan produktivitas pertanian (Yunus, 2008). Lahan 
petani yang semakin sempit akibat kebutuhan perumahan dan lahan industri menyebabkan perubahan mata pencaharian penduduk, yang semula petani menjadi bukan petani.

Selain berkembangnya alih fungsi lahan, wilayah peri-urban mengalami beberapa transformasi selain kondisi fisik yaitu transformasi sosial dan ekonomi. Yunus (2008) menyatakan bahwa trasnformasi ekonomi dilihat dari perspektif kegiatan penduduk asli dan perspektif Penduduk Pendatang. Sedangkan Transformasi Sosial dapat dilihat dari perspektif Mata Pencaharian, ketrampilan, kekerabatan, kelembagaan, strata sosial, kontrol sosial, dan mobilitas penduduk.

\section{Gambaran Umum Kecamatan Gunungpati}

Penduduk Kecamatan Gunungpati paling banyak bekerja sebagai buruh bangunan yaitu $22 \%$ dan penduduk yang bekerja menjadi petani maupun buruh tani total sebesar $34 \%$ dari total penduduk.

\section{Tabel 2. Mata Pencaharian Penduduk Kecamatan Gunungpati Tahun 2009}

\begin{tabular}{|l|l|r|}
\hline No. & \multicolumn{1}{|c|}{ Mata Pencaharian } & \multicolumn{1}{|c|}{ Jumlah } \\
\hline 1. & petani & 4.154 \\
\hline 2. & buruh tani & 3.935 \\
\hline 3. & nelayan & 15 \\
\hline 4. & pengusaha & 477 \\
\hline 5. & buruh industri & 4.697 \\
\hline 6. & buruh bangunan & 5.328 \\
\hline 7. & pedagang & 1.540 \\
\hline 8. & angkutan & 229 \\
\hline 9. & pns/abri & 1.711 \\
\hline 10. & pensiunan & 383 \\
\hline 11. & jasa/lainnya & 1.358 \\
\hline
\end{tabular}

Sumber: Kecamatan Gunungpati dalam Angka, tahun 2009

Kecamatan Gunungpati merupakan daerah yang cenderung berbukit-bukit. Morfologi wilayahnya bergelombang atau berbukit-bukit, bukan merupakan area yang rata.Sedangkan Iklim pada wilayah Kecamatan Gunung Pati termasuk kedalam iklim tropis agak basah dan memilikicurah hujan tertinggi berkisar antara $2400-2600 \mathrm{~mm} /$ tahun.

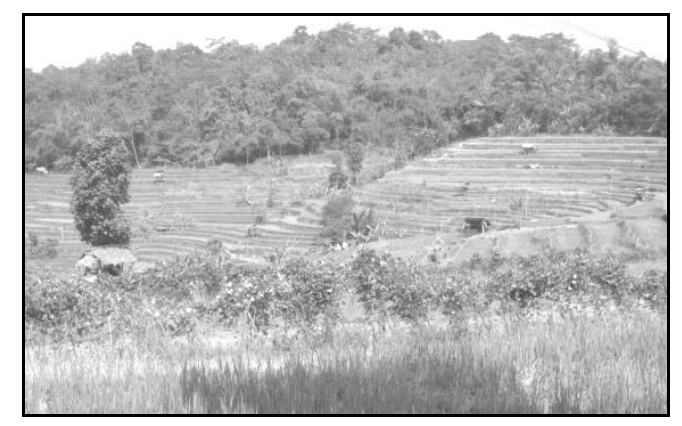

Gambar 2. Morfologi Berbukit 
Kemiringan tanah juga bervariasi, dengan topografi rata-rata di Kecamatan Gunungpati yaitu berkisar 22\% (curam). Berikut dapat dilihat gambaran kontur yang terdapat di Kecamatan Gunungpati dengan interval 10 meter.

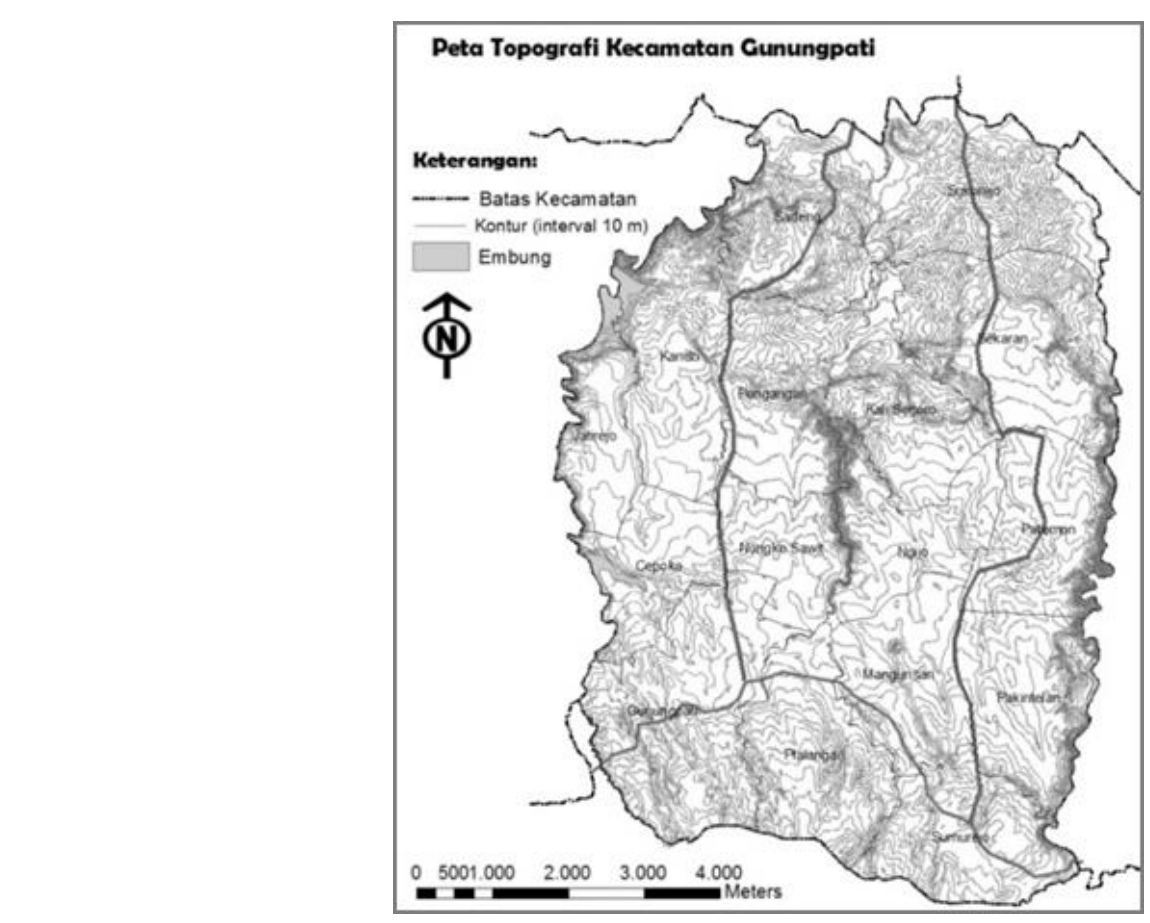

Sumber: Bappeda Kota Semarang

Gambar 3. Peta Topografi Kecamatan Gunungpati

\section{Analisis Perkembangan Pemanfaatan Lahan di Kecamatan Gunungpati}

Kecamatan Gunugpati merupakan pinggiran Kota Semarang dimana di sana masih banyak terdapat lahan pertanian baik pertanian lahan basah (sawah) maupun tegalan. Akan tetapi, seiring perkembangan kota, lahan-lahan pertanian tersebut dialih fungsikan menjadi lahan untuk aktivitas non pertanian atau menjadi permukiman dan bangunan lain. Dalam kasus ini akan digambarkan bagaimana pola konversi lahan di Kecamatan Gunungpati secara time series dari tahun 1994, 2001, 2006, dan tahun 2010 menggunakan citra landsat yang telah diolah.

Dari gambar peta tutupan lahan, dapat diketahui bahwa konversi lahan yang dulunya merupakan lahan pertanian menjadi lahan terbangun pada tahun 1994 ke tahun 2001 terjadi di bagian utara yaitu Kelurahan Sadeng dan Kelurahan Sukorejo yang merupakan kelurahan yang paling dekat dengan pusat kota dan pada Kelurahan Sekaran yang merupakan lokasi dari Universitas negeri Semarang 
182 Identifikasi Alih Fungsi Lahan Pertanian dan Kondisi Sosial Ekonomi Masyarakat Daerah Pinggiran
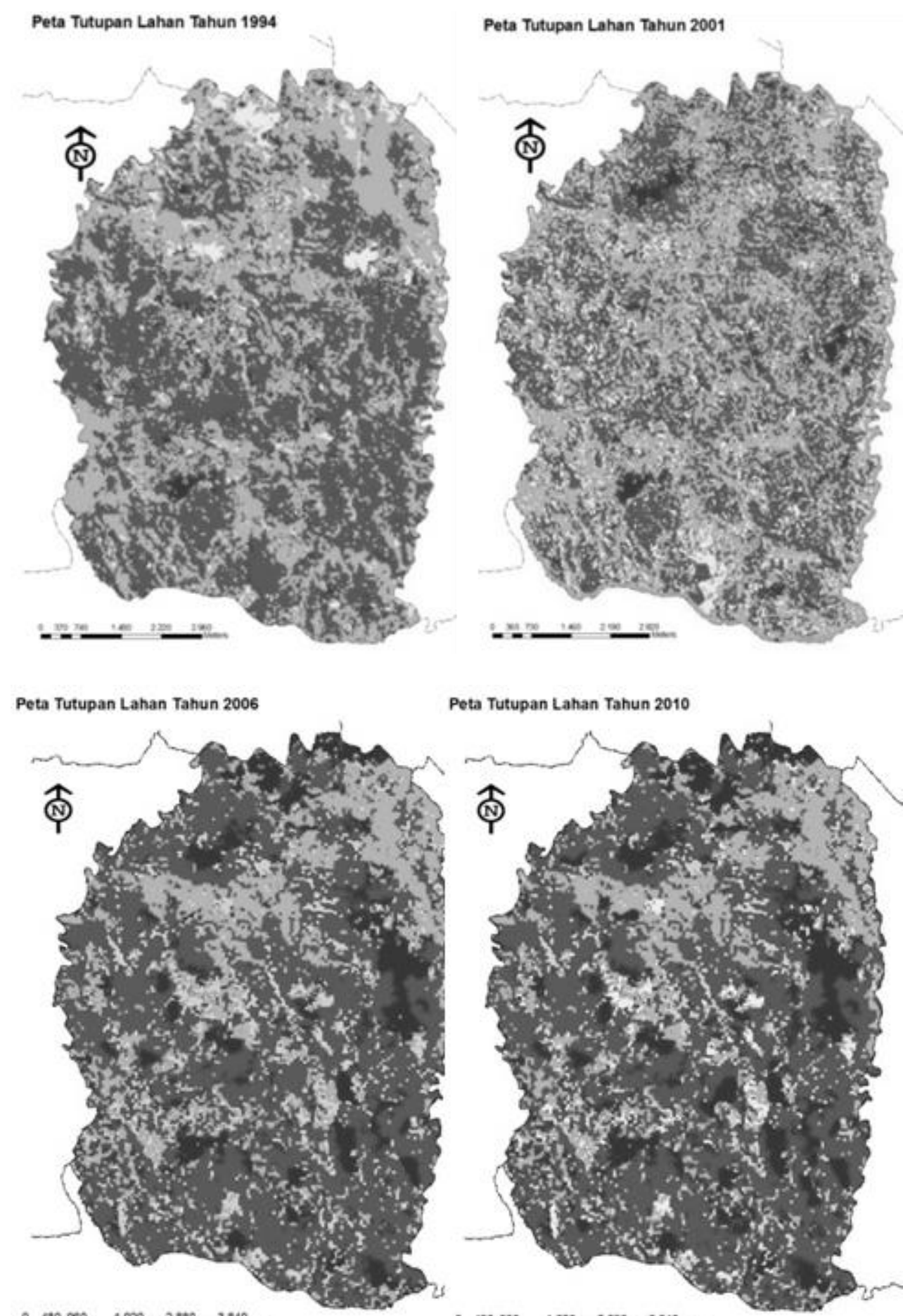

Peta Tutupan Lahan Tahun 2010
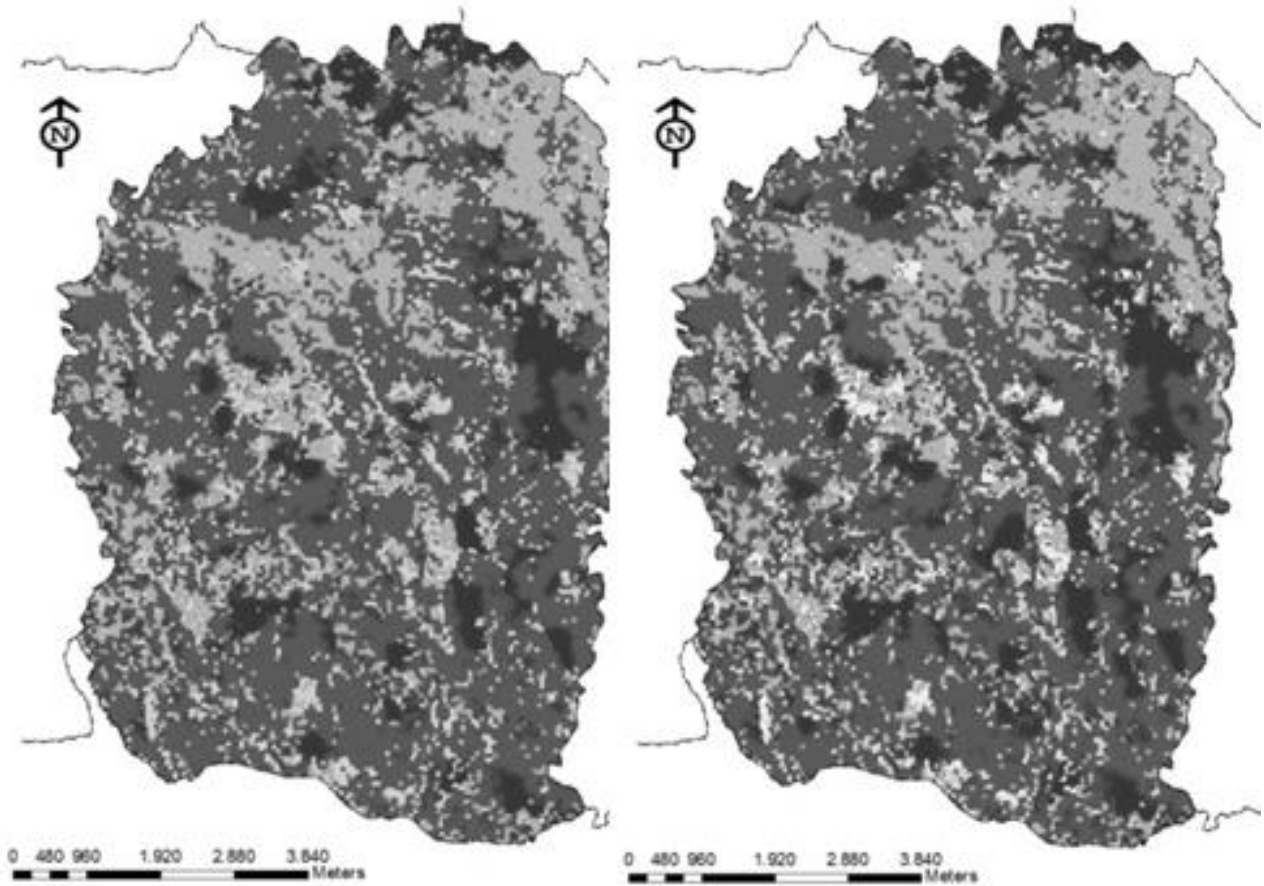

\section{Keterangan:}

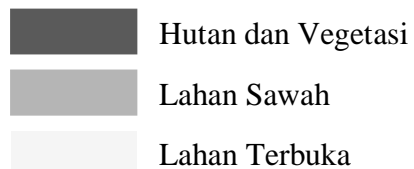

Badan Air

Permukiman dan Bangunan

Tegalan

Gambar 4. Peta Tutupan Lahan Kecamatan Gunungpati Tahun 1994 (kiri) dan 2001 (kanan) 
Begitu juga pada tahun 2001 ke tahun 2006 dan 2010 terjadi perkembangan permukiman yang semakin banyak pada area-area yang telah disebutkan tadi. Permukiman yang semakin pada di bagian utara, dan bangunan yang juga semakin meluas di area UNNES yaitu di Kelurahan Sekaran.

Meluasnya area terbangun di Kecamatan Gunungpati terjadi di beberapa titik tertentu saja, hal ini dapat dikarenakan adanya faktor alamiah yaitu bentuk atau morfologi kecamatan ini adalah berbukit-bukit dan mempunyai kelerengan yang curam.

Penelitian ini menekankan pada perubahan lahan pertanian yaitu tegalan dan sawah yang telah menjadi lahan terbangun atau non pertanian. Peta berikut ini menunjukkan perubahan lahan yang ditunjukkan dengan: warna coklat untuk lahan terbangun yang dulunya merupakan lahan tegalan, dan hijau untuk lahan terbangun yang dulunya merupakan lahan sawah. Selebihnya yaitu yang tidak berwarna atau yang berwarna putih adalah lahan-lahan peruntukan lain termasuk lahan pertanian yang tidak terjadi perubahan, sehingga dalam hal ini diabaikan.

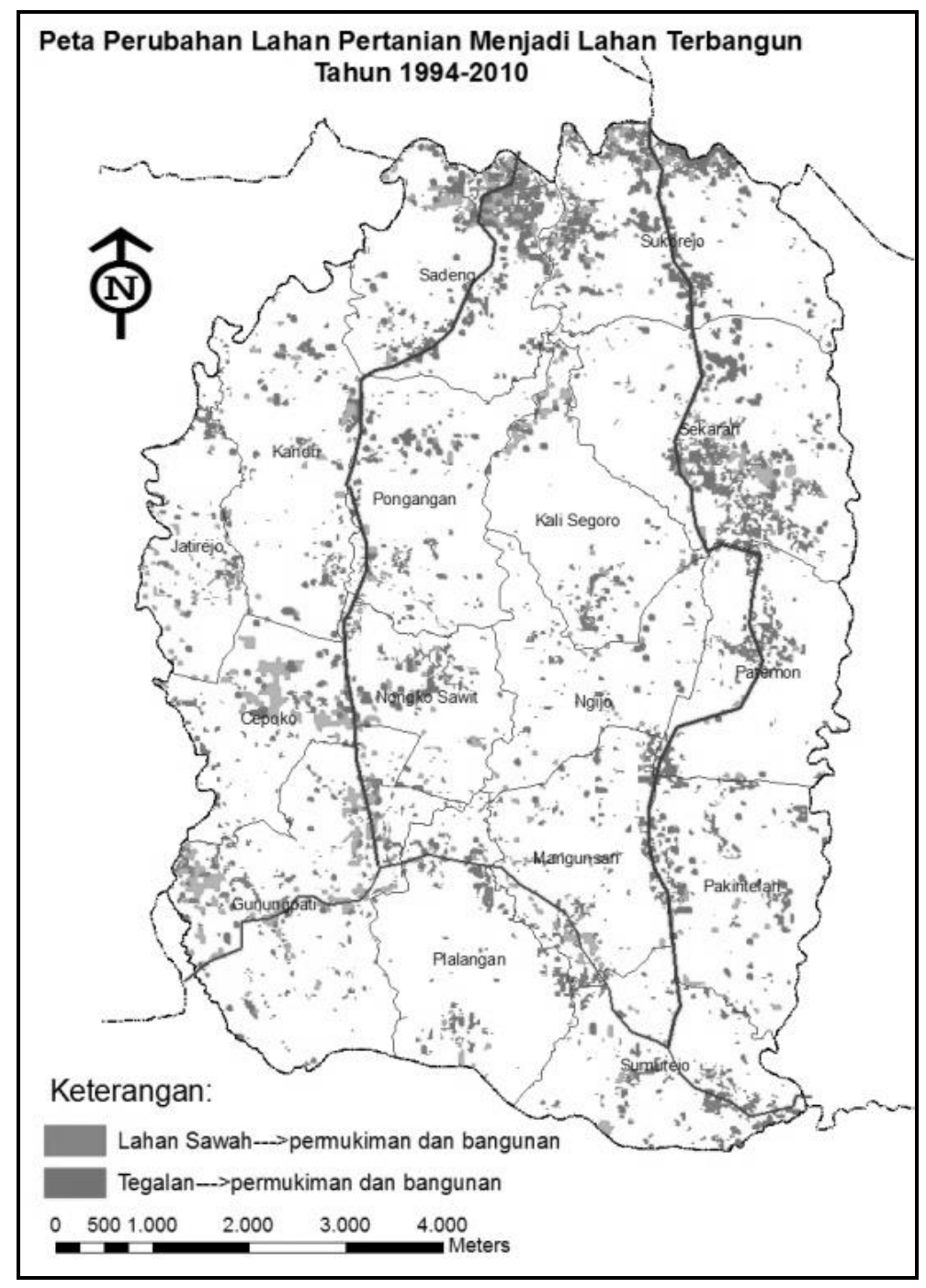

Gambar 5. Peta Perubahan Lahan Pertanian menjadi Lahan Terbangun (Tahun 1994-2010) 
Perubahan luas lahan pertanian menjadi lahan terbangun di Kecamatan dalam kurun waktu 16 tahun (tahun 1994-2010) untuk lahan pertanian basah atau sawah sekitar 384,40 $\mathrm{Ha}$, dan untuk perubahan lahan pertanian kering atau tegalan yang telah menjadi lahan terbangun yaitu sekitar 414,41 Ha.

Tabel 3. Perubahan Luas Lahan Pertanian Menjadi Lahan Terbangun

\begin{tabular}{|c|c|c|c|c|}
\hline \multirow[b]{2}{*}{ Tipe Konversi } & \multicolumn{4}{|c|}{ Luas Konversi (ha) } \\
\hline & $\begin{array}{l}\text { Th } 1994 \text { s.d } \\
2001\end{array}$ & $\begin{array}{l}\text { Th } 2001 \text { s.d } \\
\quad 2006\end{array}$ & $\begin{array}{l}\text { Th } 2006 \text { s.d } \\
2010\end{array}$ & $\begin{array}{l}\text { Total } 1994 \text { s.d } \\
2010\end{array}$ \\
\hline $\begin{array}{l}\text { Sawah } \rightarrow \text { Permukiman } \\
\text { dan Bangunan }\end{array}$ & 49,57 & 112,96 & 221,86 & 384,40 \\
\hline $\begin{array}{l}\text { Tegalan } \rightarrow \text { Permukiman } \\
\text { dan Bangunan }\end{array}$ & 96,41 & 197,58 & 120,4 & 414,41 \\
\hline
\end{tabular}

Perkembangan alih fungsi lahan pertanian ini banyak terjadi pada area yang strategis, seperti area yang dekat dengan pusat kota, kawasan pendidikan, pinggiran jalan utama, dan pada koridor "pintu masuk" Kecamatan Gunungpati.Hal ini terkait adanya perkembangan kota hingga ke daerah pinggiran, pembangunan infrastruktur dan sarana pada kawasan yang dekat dengan kota dan pada kawasan pendidikan UNNES sehingga banyak penduduk pendatang yang tinggal di sana.

\section{Transformasi Karakteristik Sosial Ekonomi}

Adanya alih fungsi lahan terutama lahan pertanian di sana telah membawa perubahan pada area-area tertentu, yaitu pada area dekat pusat kota, kawasan pendidikan, dan yang dekat pada koridor jalan utama pintu masuk Kecamatan Gunungpati. Perubahan yang dapat secara nyata dirasakan oleh penduduk asli Kecamatan Gunungpati adalah beralihnya sumber mata pencaharian mereka (transformasi ekonomi), dari petani menjadi bukan petani. Petani yang mempunyai modal lebih dan ketrampilan lebih dapat melangsungkan hidupnya dengan membuka usaha atau berdagangseperti buka warung, buka kos-kosan, toko, dll sehingga pendapatannya bertambah. Sedangkan petani yang kurang mempunyai modal dan ketrampilan mereka biasanya menjadi buruh tani atau buruh serabutan.

Seiring perkembangan kota dan proses alih fungsi lahan pertanian menjadi lahan terbangun untuk aktivitas non-pertanian, ada beberapa perubahan yang terjadi dalam struktur sosial dalam masyarakat periurban. Perubahan ini terjadi terutama pada area-area pengembangan yang telah dijelaskan di atas. Biasanya pemilik lahan pertanian berada dalam satu rumpun atau satu lokasi dalam suatu area tertentu yang kemudian secara hampir bersamaan pula lahan pertanian mereka dijual. Kemudian karena tidak adanya kelanjutan aktivitas ekonomi, mereka mencari kegiatan ekonominya masing-masing secara berbeda. Oleh karena itu walaupun mereka masih dalam satu lokasi, adanya perbedaan aktivitas ekonomi dan masuknnya penduduk pendatang pada area mereka membuat kekerabatan antar warga menjadi memudar. 


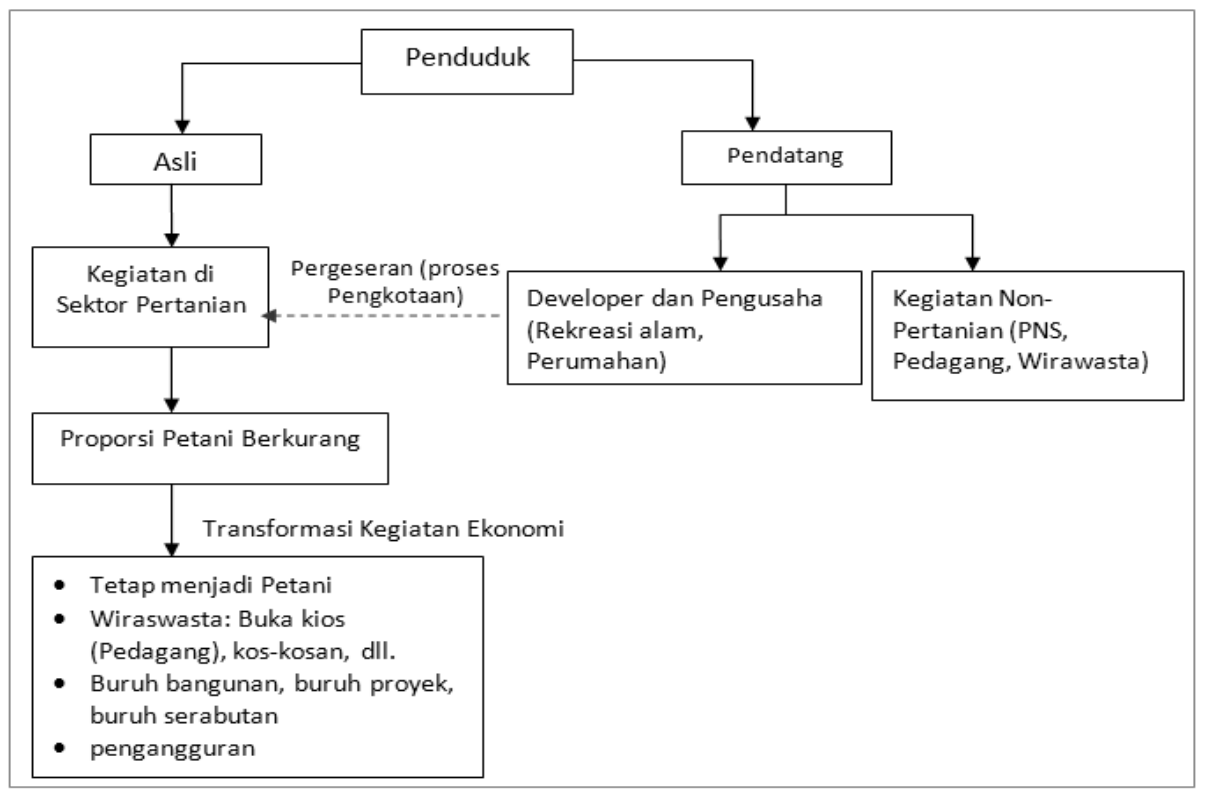

\section{Gambar 6. Skema Transformasi Kegiatan Ekonomi Penduduk di Kecamatan Gunungpati}

Perubahan tersebut nantinya akan berujung pada memudarnya kekerabatan antar warga seperti yang telah dikemukakan oleh Yunus (2008) yaitu terjadi dekohesivitas kerabatan sosial yaitu berkurangnya kekerabatan antar warga yaitu darimasyarakat yang kekerabatnnya kental atau paguyuban (gemeinschaft) menjadi pudar dan individualistik (gesselschaft).

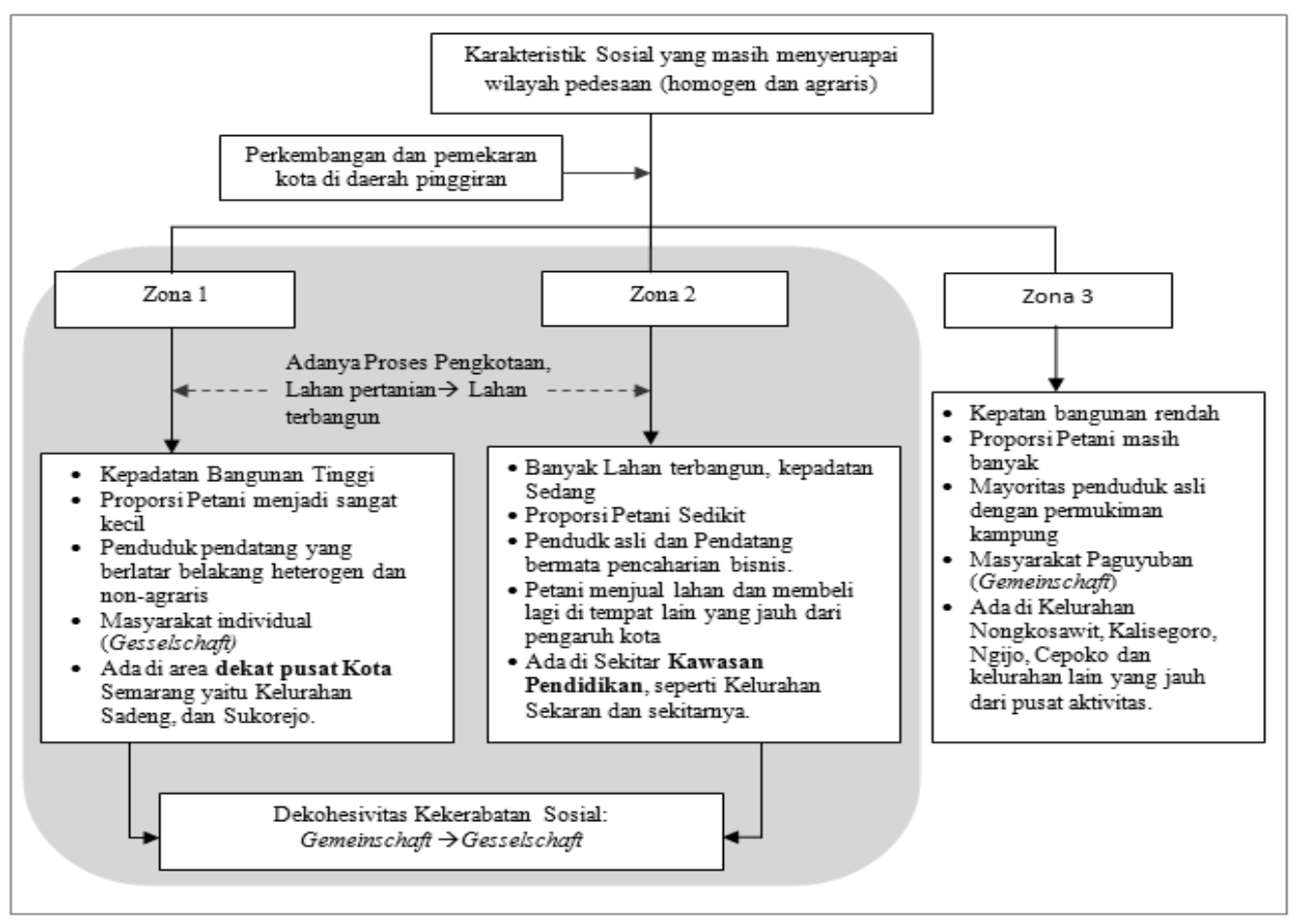

Gambar 8. Skema Transformasi Kondisi Sosial Masyarakat di Kecamatan Gunungpati 


\section{Kesimpulan}

Alih fungsi lahan pertanian di pinggiran Kota Semarang dalam hal ini di Kecamatan Gunungpati terjadi secara progresif pada area-area tertentu atau area pengembangan, seperti pada area dekat dengan pusat kota, kawasan pendidikan, dan pada area strategis lain yaitu pada koridor lain atau pintu masuk ke Kecamatan Gunungpati.

Perubahan kondisi sosial ekonomi secara nyata dirasakan oleh penduduk asli Kecamatan Gunungpati yang dulunya menjadi petani. Petani yang kehilangan lahan sawahnya tersebut mayoritas mengalami penurunan pendapatan. Hal ini dikarenakan tingkat pendidikan dan ketrampilan para petani yang terbatas atau tergolong rendah sehingga mereka tidak dapat mengakses pekerjaan formal.

Selain itu, perubahan juga terasa pada kondisi sosial masyarakat yang berada pada area-area pengembangan tersebut. Perubahan tersebut nantinya akan berujung pada memudarnya kekerabatan antar warga.

\section{Daftar Pustaka}

Agus, Fahmuddin dan Irawan. __. Alih Guna dan Aspek Lingkungan Lahan Sawah, dalam http://balittanah.litbang.deptan.go.id/

Badan Pusat Statistik. 2008. Kecamatan Gunungpati Dalam Angka 2008

Daniel, Moehar. 2005. Metode Penelitian Sosial Ekonomi. Jakarta: Bumi Aksara.

DFID (Department For International Development). 2003. Sustainable Livelihoodsdalam Currents. Swedish University Of Agricultural Sciences

Doppler, Werner. 2006. Resources and livelihood in mountain areas of South East Asia: Farming and rural systems in a changing environment. Wekersheim: MargrafVerlag.

Ellis, Frank. 1999. Rural Livelihood Diversity In Developing Countries: Evidence And Policy Implications. Overseas Development Institute.

Fatah, Luthfi. 2006. Dinamika Pembangunan Pertaniandan Pedesaan. Banjar Baru: Pustaka Benua.

Hariyanto. 2010. Pola dan Intensitas Konversi Lahan Pertanian di Kota Semarang Tahun 2000-2009, dalam http://unnes.ac.id

Hiremath, B.N. 2007. The Changing Faces Of Rural Livelihoods In India. National Civil Society Conference.Institute of Rural Management, Anand.

Li, Jin and Andrew D. Heap. 2008. A Review of Spatial Interpolation Methods for Environmental Scientists. Geoscience Australia Record 2008/23, dalam http://www.ga.gov.au/GA12526.pdf

Lubis, A. E. 2005. Perencanaan Koorporasi Peningkatan Ketahanan Pangan Di PropinsiSumatera Utara. Badan Ketahanan Pangan Propinsi Sumatra Utara, Medan. dalam http://repository.usu.ac.id/

Melati, Rampi. 2011. Pengaruh Konversi Lahan Terhadap Harga Jual Rumah Untuk Masyarakat Berpenghasilan Rendah Di Kecamatan Tembalang. Tugas Akhir Jurusan Perencanaan Wilayah dan Kota Fakultas Teknik Undip.

Nasution, Rozaini. 2003. Teknik Sampling, dalam http://library.usu.ac.id/download/fkm/fkm-rozaini.pdf.

Peraturan Daerah Kota Semarang Nomor 13 Tahun 2004 Tentang Rencana Detail Tata Ruang Kota (RDTRK) Kota Semarang Bagian Wilayah Kota VIII (Kecamatan Gunungpati) Tahun 2000 - 2010

Prakoso, Yogo. 2011. Pemanfaatan Sumberdaya sebagai upaya peningkatan Ketahanan Sosial Ekonomi Masyarakat Desa Sayung. Tugas Akhir Jurusan Perencanaan Wilayah dan Kota Fakultas Teknik Undip.

Pramono, G. H. 2008. Akurasi Metode IDW dan Kriging untuk Interpolasi Sebaran Sedimen Tersuspensi di Maros Sulawesi Selatan, Forum Geografi, Vol. 22, No. 1, Juli 2008: 145-158. 
Prasasti, Indah et. al. 2005. Analisis Penerapan Metode Krigging Dan Invers Distance Pada Interpolasi Data Dugaan Suhu, Air Mampu Curah (Amc) Dan Indeks Stabilitas Atmosfer (Isa) Dari Data Noaa-Tovs. Pertemuan Ilmiah Tahunan MAPIN XIV, dalam http://www.google.co.id/

Rencana Pembangunan Jangka Menengah Daerah (RPJMD) Kota Semarang Tahun 2010-2015

Rudiarto, Iwan. 2010. Spatial Assessment of Rural Resources and Livelihood Development in Mountain Area of Java: A Case from Central Java - Indonesia. Wekersheim: Margraf Verlag.

Rudiarto, Iwan dan Wiwandari Handayani. 2011. Spatial Differentiation Of Sosioeconomics And Infrastructure Development In Rural's Mountain Area.

Saragih, Sebastian, et. al. 2007. Kerangka Penghidupan Berkelanjutan Sustainable Livelihood Framework, dalam http://www.zef.de/module/register/media/2390_SL-Chapter1.pdf

Saugi, Ahmad. 2009. Masyarakat Perkotaan dan Masyarakat Pedesaan, dalam http://achmadsaugi.wordpress.com/2009/12

Sumaryanto dan Iqbal. Tanpa Tahun . Konversi Lahan Sawah ke Penggunaan Nonpertanian dan Dampak Negatifnya, dalamhttp://balittanah.litbang.deptan.go.id

Susanto, EriAgus. 1999. Alih Fungsi Lahan Pertanian dan Perubahan kehidupan sosial ekonomi petani di wilayah perbatasan kabupaten Dati II Demak. Tugas Akhir Jurusan Perencanaan Wilayah dan Kota Fakultas Teknik Undip.

Wahyuni, Novianti. 2002. Pengaruh Keberadaan Perguruan Tinggi Terhadap Perkembangan Struktur Dan Bentuk Kawasan Pinggiran (studikasus: Kelurahan Sekaran). Tesis Magister Pembangunan Wilayah dan Kota Undip.

Yunus, Hadi Sabari. 2008. Dinamika Wilayah Peri-Urban Determinan Masa Depan Kota. Yogyakarta: Pustaka Pelajar. 
188 Identifikasi Alih Fungsi Lahan Pertanian dan Kondisi Sosial Ekonomi Masyarakat Daerah Pinggiran

JURNAL WILAYAH DAN LINGKUNGAN, 1 (2), 175-188 